$$
\begin{aligned}
& \text { Hafiz Riyadli, Arliyana \& Agus Wanto. Sistem Informasi Akademik Siswa Berbasis } \\
& \text { Web Mobile }
\end{aligned}
$$

\title{
SISTEM INFORMASI AKADEMIK SISWA BERBASIS WEB MOBILE
}

\author{
Hafiz Riyadli ${ }^{1}$, Arliyana ${ }^{2}$, Agus Wanto ${ }^{3}$ \\ ${ }^{1}$ Program Studi Sistem Informasi, ${ }^{2}$ Program Studi Manajemen Informatika, ${ }^{3}$ Program Studi Sistem \\ informasi, STMIK Palangkaraya Jl. George Obos No. 114 Palangka Raya, 73112 \\ Telp./Faks: (0536) 3225515/ (0536) 3236933, e-mail: hafizriyadli@ stmikplk.ac.id
}

\section{Email : ${ }^{1}$ hafiz.riyadli@gmail.com, ${ }^{2}$ arliyana.85@gmail.com, ${ }^{3}$ agus.wanto190294@gmail.com}

\begin{abstract}
This research aims to: 1) generate an application for academic information systems in order to support academic activities at SMAN 1 Kumai Kotawaringin Barat so that the academic process of learning in the school can be recorded neatly and efficiently ; 2) information generated by the system is the schedule of lessons, teaching materials, discussion forums and teacher assessments that can be seen by students, and reports of results from the assessments entered by the teacher; 3) This information system is made able to run well on the Internet network both on the personal computer or mobile device accessed through the mobile web platform.
\end{abstract}

Keywords : Academic Information Systems, Mobile Web Platform

\begin{abstract}
ABSTRAK
Penelitian ini bertujuan untuk : 1) menghasilkan sebuah aplikasi sistem informasi akademik dalam rangka mendukung Aktivitas akademik pada SMAN 1 Kumai Kotawaringin Barat sehingga proses akademik pembelajaran di sekolah tersebut dapat tercatat rapi dan efisien; 2) Informasi yang di hasilkan sistem yaitu berupa jadwal pelajaran, bahan ajar, forum diskusi dan penilaian guru yang dapat di lihat oleh siswa,dan laporan hasil dari penilaian yang di masukkan oleh guru; 3) sistem informasi ini dibuat mampu berjalan dengan baik pada jaringan internet baik pada perangkat personal komputer maupun perangkat mobile yang diakses melalui platform web mobile.
\end{abstract}

\section{Kata kunci : Sistem Informasi Akademik, Platform web mobile}

\section{PENDAHULUAN}

Seiring dengan era globalisasi teknologi saat ini, kebutuhan informasi dalam pendidikan menjadi sangat penting dalam menentukan kemajuan suatu sekolah. Aktivitas yang baik pada suatu sekolah atau teknologi pun sangat ditentukan oleh informasi yang tersedia. Untuk mengelola informasi yang tersedia dibutuhkan teknologi informasi yang dapat mengorganisir dengan baik data-data sekolah secara terstruktur dan mudah dipahami dengan baik.

Dalam hal ini pemanfaatan internet dapat membantu pihak sekolah untuk mengembangkan informasi berbasiskan website tentang informasi akademik, sehingga para guru tidak perlu menyampaikan hasil absensi, jadwal pelajaran, maupun penilaian para siswa-siswi dengan membagikan kembali kertas yang sudah diperiksa, hanya cukup dengan menggunakan komputer atau handphone dan mengakses aplikasi ini maka para guru, siswa-siswi sudah dapat melihat absensi, jadwal pelajaran, maupun penilaian para siswasiswi dengan mudah. Untuk mencapai tujuan tersebut, maka SMAN 1 Kumai Kotawaringin Barat membutuhkan sebuah aplikasi untuk menyapaikan sistem informasi akademik siswa yang berbasiskan website (online), yang juga dapat di akses melalui perangkat mobile dengan baik.

\section{TINJAUAN PUSTAKA \\ 2.1 Penelitian yang Relevan \\ Penelitian Imelda dan Erik (2014), mengungkapkan bahwa Sistem Informasi Akademik dapat membantu dalam proses pencarian data dan pembuatan laporan untuk mengetahui sejauh mana proses pencarian data dan pembuatan laporan yang berbasis komputer dapat dilakukan}




$$
\begin{array}{r|l}
\text { Jurnal Sains Komputer dan Teknologi Informasi } & \text { Page } \\
\text { e-issn: 2655-7460. Volume 2 No.1, November 2019 } & 11-15
\end{array}
$$

secara baik dan efektif sehingga dapat mempermudah pelaksanaan tugas akademik.

Pada penelitian sebelumnya Suryandani, dkk (2017) menghasilkan sebuah sistem informasi berbasis web pengelolaan nilai untuk memudahkan guru dalam mengelola nilai rapor siswa. Metode yang digunakan dalam penelitian ini adalah metode penelitian dan pengembangan (R\&D) yang dilaksanakan di SMK Negeri 1 Kudus.

Djaelangkara, dkk (2015), menggunakan metode Waterfall, perancangan sistem informasi akademik berbasis web ini dapat meningkatkan kualitas pengolahan data akademik di SMAK 1 Tomohon, membantu mempermudah pengolahan data akademik sekolah dan lebih maksimal dan praktis karena dapat di akses dari mana saja sekaligus menjaga data tetap aman.

Susanti (2016), Perancangan sistem informasi akademik berbasis web menggunakan metode Waterfall yang dapat memberikan pelayanan optimal kepada siswa dan orang tua sehingga tidak perlu datang ke sekolah untuk mendapatkan informasi akademik, sehingga dihasilkan informasi yang cepat dan akurat.

Alpiandi (2016), Pengembangan sistem berupa pembuatan sistem informasi akademik berbasis web pada SMP Negeri 2 Kecamatan Gaung Anak Serka, merupakan sistem yang memberikan informasi laporan siswa secara Online yang berupa laporan nilai siswa yang bersangkutan, jadwal pelajaran, dan data pengajar, sehingga membantu kecepatan dan kualitas dalam penyampaian informasi.

Terakhir Membara, dkk (2014), Merancang dan merealisasikan sistem informasi akademik SMP Negeri 2 Talang Empat berbasis web sebagai media alternatif penyedia informasi, sehingga mempermudah dalam pencarian data mengenai Sekolah.

\subsection{Model Pengembangan Perangkat Lunak}

Model Pengembangan Perangkat Lunak yang digunakan adalah Model Prototype, yaitu suatu model proses perangkat lunak yang telah secara eksplisit dirancang untuk mengakomodasi suatu produk yang akan bertambah secara perlahan (berevolusi) sepanjang waktu. Model ini bersifat iterative, dicirikan dalam bentuk yang memungkinkan kita mengembangkan perangkat lunak yang semakin kompleks pada versi-versi berikutnya (Pressman, 2010:50).

Pembuatan Prototype dimulai dengan dilakukannya komunikasi antara tim pengembang perangkat lunak dengan pelanggan, perencanaan dan pemodelan perancangan secara cepat, pembentukan prototype, selanjutnya penyerahan sistem kepada pengguna yang akan memberikan umpan balik untuk digunakan pada iterasi pengembangan perangkat lunak selanjutnya. Seperti yang dapat dilihat pada gambar berikut.

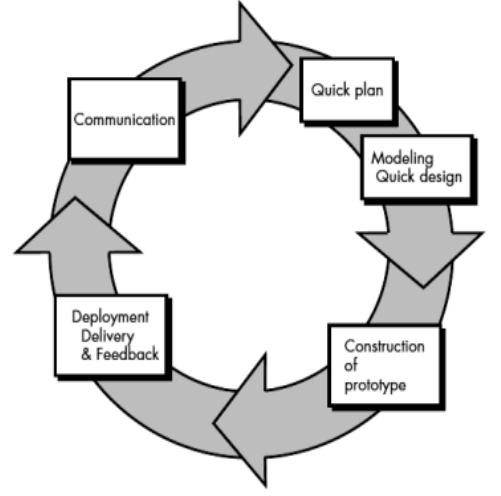

Gambar 1. Model Prototype (Pressman, 2010)

\subsection{Platform Web Mobile}

Sementara Platform Web Mobile sendiri merupakan aplikasi akses internet menggunakan peralatan yang bersifat mobile berbasis browser yang bertujuan untuk mengakses layanan data secara wireless dengan menggunakan perangkat mobile seperti handphone, PDA dan perangkat portable yang tersambung ke sebuah jaringan telekomunikasi seluler (Khairullah, 2016).

Secara platform, pengembangan sistem informasi akademik berbasis web mobile memiliki berbagai keunggulan daripada platform web biasa. Pertama, sistem informasi berbasis web mobile menggunakan browser untuk mengakses system, sehingga tidak membebani memori perangkat untuk instalasi sistem. Kedua, sistem informasi berbasis web mobile menghasilkan tampilan yang lebih user friendly ketika diakses lewat perangkat mobile. Ketiga, perangkat mobile yang digunakan untuk mengakses sistem ini memiliki fleksibilitas yang lebih tinggi dibanding perangkat akses web konvensional seperti PC dan Laptop. Dan Keempat, Guru dan Tenaga Kependidikan serta Siswa lebih sering menggunakan perangkat mobile/ smartphone sehingga Sistem Informasi akademik yang dikembangkan berbasis web mobile lebih relevan dengan kebutuhan pengguna.

\section{METODE PENELITIAN}

\subsection{Metode Research and Development}

Pada penelitian yang telah dikemukakan sebelumnya tidak terdapat kombinasi metode Research and Development yang digunakan untuk membangun Sistem Informasi Akademik berbasis Web Mobile.

Metode Research and Development (penelitian dan pengembangan) sendiri telah banyak digunakan dibidang ilmu-ilmu teknologi 
informasi. Hampir semua produk teknologi diproduksi dan dikembangkan melalui penelitian dan pengembangan (Guritno dkk, 2011).

\subsection{Metode Pengumpulan Data}

\subsubsection{Wawancara}

Melakukan dialog langsung kepada Guru, tenaga kependidikan dan siswa di SMAN 1 Kumai Kabupaten Kotawaringin Barat.

\subsubsection{Observasi}

Mengamati kegiatan yang dilakukan oleh guru, tenaga kependidikan, serta kepada siswa dalam melaksanakan kegiatan administrasi akademik

\subsubsection{Kepustakaan}

Mengumpulkan dan mempelajari sejumlah buku, artikel, jurnal, serta referensi yang berhubungan dengan system informasi akademik.

\subsubsection{Dokumentasi}

Mempelajari dokumen - dokumen administrasi yang berkaitan dengan sistem informasi akademik.

\subsubsection{Kuisioner}

Memberikan seperangkat pertanyaan atau pernyataan kepada responden (guru, tenaga kependidikan dan siswa) yang berkaitan dengan sistem informasi akademik.

\section{HASIL DAN PEMBAHASAN}

\subsection{Rancangan Sistem}

Sistem ini dirancang menggunakan Diagram UML. Pada rancangan Use Case, ada tiga level pengguna sistem yaitu Admin, Guru dan Siswa. Masing-masing level pengguna sistem ini memiliki hak akses yang terbatas sesuai dengan hak akses pada levelnya masing-masing. Berikut ini adalah diagram rancangan sistem.

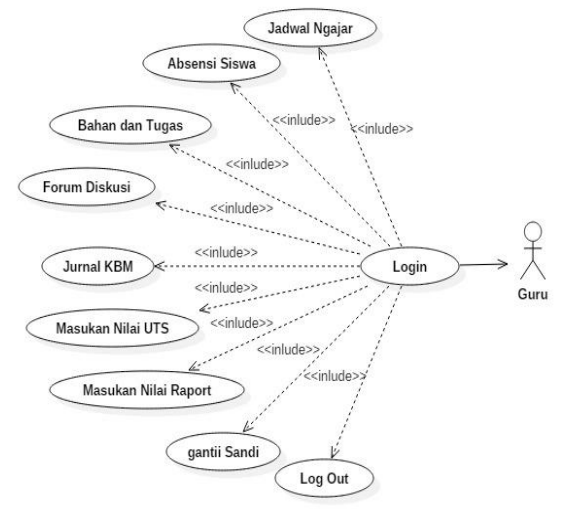

Gambar 2. Use Case Level Guru

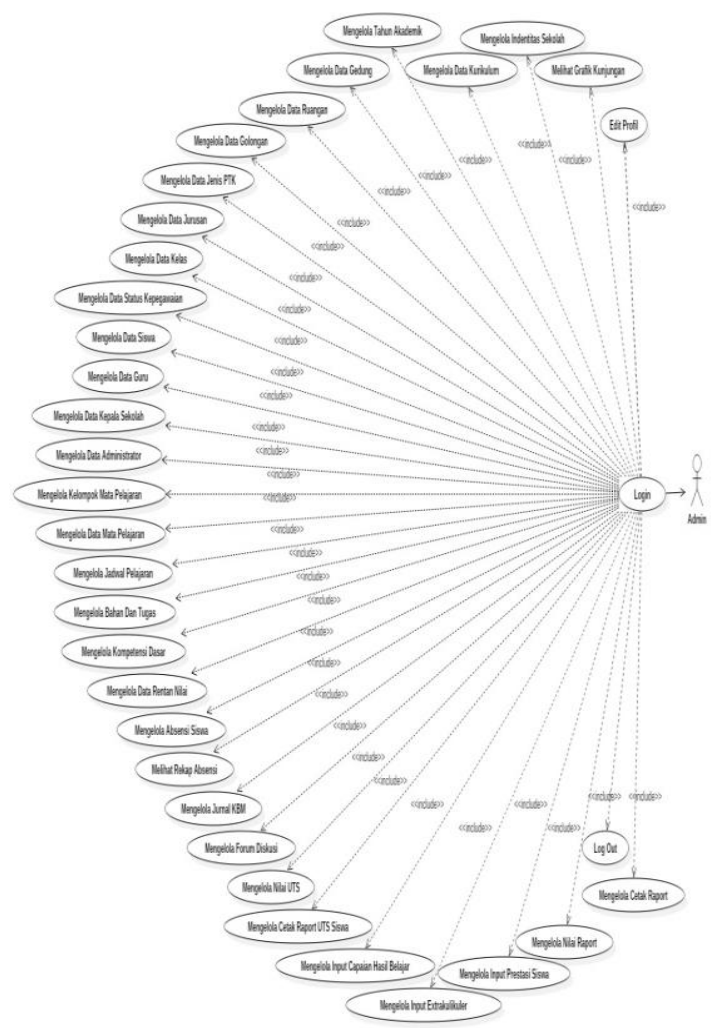

Gambar 3. Use Case Level Admin

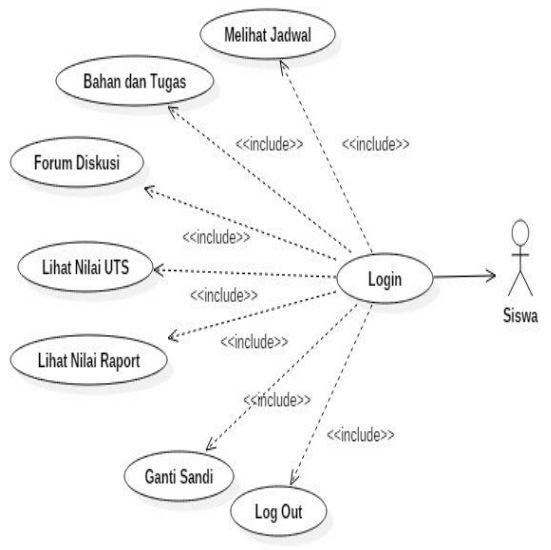

Gambar 4. Use Case Level siswa

\subsection{Implementasi dan Pengujian Sistem}

Sistem informasi akademik yang dihasilkan berbasis web, yang dapat diakses melalui web browser. Memiliki beberapa fitur sesuai dengan kebutuhan objek yaitu data master, data pengguna, data akademik, data absensi, jurnal KBM, forum diskusi dan data nilai siswa. Sistem ini juga dilengkapi dengan menu login sebagai dinding keamanan sekaligus jalan memverifikasi level dari pengguna sistem. 


\section{Jurnal Sains Komputer dan Teknologi Informasi Page e-issn: 2655-7460. Volume 2 No.1, November $2019 \mid 11-15$}

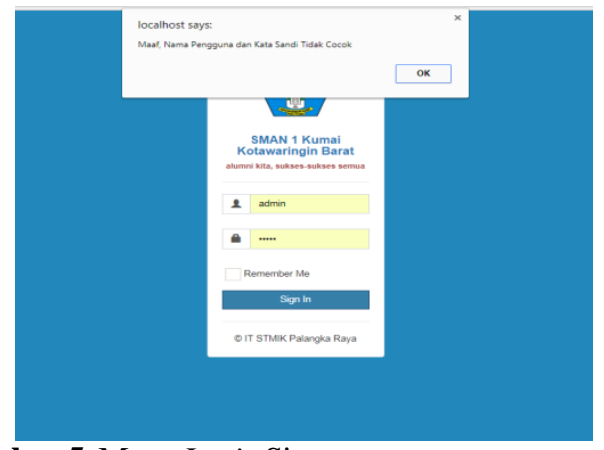

Gambar 5. Menu Login Sistem

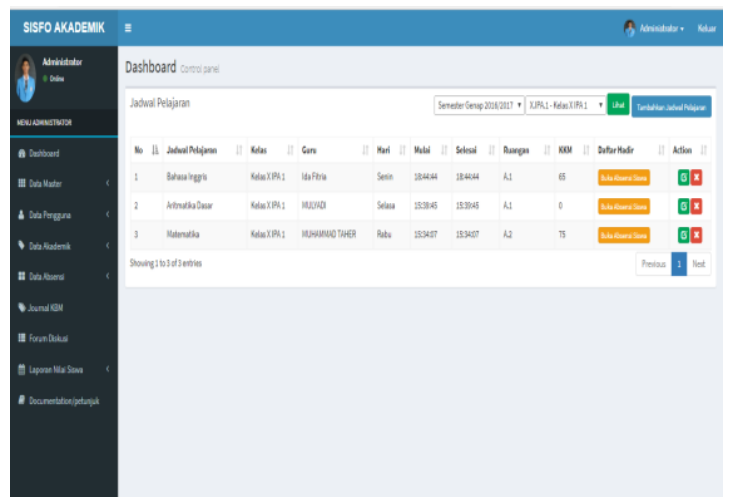

Gambar 6. Menu Utama Sistem

Selanjutnya, sistem ini diuji menggunakan metode blackbox testing, yang hasilnya dapat dilihat pada tabel dibawah ini :

Tabel 1. Tabel Pengujian dengan Blackbox Testing

\begin{tabular}{|c|c|c|c|}
\hline No & Skenario Pengujian & $\begin{array}{l}\text { Hasil yang } \\
\text { Diharapkan }\end{array}$ & $\begin{array}{c}\text { Kesimpul } \\
\text { an }\end{array}$ \\
\hline 1 & $\begin{array}{l}\text { Mengisi Username } \\
\text { dan Password } \\
\text { dengan isi yang } \\
\text { salah } \\
\text { (Form Login) }\end{array}$ & $\begin{array}{l}\text { Sistem menolak } \\
\text { akses }\end{array}$ & Valid \\
\hline 2 & $\begin{array}{l}\text { Mengisi Data Guru } \\
\text { dengan NIK berisi } \\
\text { huruf dan karakter } \\
\text { (Form Master Data } \\
\text { Guru) }\end{array}$ & $\begin{array}{l}\text { Sistem Menolak } \\
\text { menyimpan } \\
\text { data }\end{array}$ & Valid \\
\hline 3 & $\begin{array}{l}\text { Mengisi nilai angka } \\
\text { dengan input huruf } \\
\text { (form data nilai) }\end{array}$ & $\begin{array}{l}\text { Sistem Menolak } \\
\text { menyimpan } \\
\text { data }\end{array}$ & Valid \\
\hline 4 & $\begin{array}{l}\text { Guru memilih } \\
\text { Mapel yang bukan } \\
\text { Mapel yang } \\
\text { diajarnya untuk } \\
\text { Mengisi Nilai }\end{array}$ & $\begin{array}{l}\text { Sistem Menolak } \\
\text { masuk ke menu } \\
\text { mapel }\end{array}$ & Valid \\
\hline
\end{tabular}

\section{KESIMPULAN DAN SARAN}

Berdasarkan dari hasil pengujian sistem maka dapat disimpulkan bahwa Sistem ini dapat mengelola dan menghasilkan informasi akademik sesuai dengan harapan untuk mempermudah guru, tenaga kependidikan dan siswa dalam melaksanakan kegiatan akademik di SMAN-1 Kumai.

Sedangkan saran penulis untuk kedepan jika melihat perkembangan teknologi sekarang ini yang lebih mengarah kepada perkembangan teknologi mobile, maka kedepan diharapkan system ini dapat ditingkatkan lagi menjadi system yang berbasis mobile.

\section{DAFTAR PUSTAKA}

Andi. 2013. Pengembangan Aplikasi Web Mobile, Setia Kawan Press, Jakarta.

Alpiandi, M. Rizki. 2016. "Sistem Informasi Akademik di SMP Negeri 2 Kecamatan Gaung Anak Serka”, Jurnal Sistemasi, Vol. 5, No. 3, Hal. 8 - 13.

Arief. 2011. Pemrograman Web Dengan PHP dan MySQL, Gramedia, Jakarta.

Djaelangkara, Recky T., Rizal Sengkey, dan Oktavian A. Lantang. 2015. "Perancangan Sistem Informasi Akademik Sekolah Berbasis Web Studi Kasus Sekolah Menengah Atas Kristen 1 Tomohon", Jurnal Teknik Elektro dan Komputer, Vol. 4, No. 3, Hal. 86-94.

Guritno, Suryo., Sudaryono, dan Untung Rahardja. 2011. Theory and Application of IT Research, Penerbit Andi, Yogyakarta.

Husein Alatas. 2013. Responsive Web Design dengan PHP \& Bootstrap, Lokomedia, Yogyakarta.

Imelda, dan Muhammad Erik. 2014."Perancangan Sistem Informasi Akademik Pada Sekolah Dasar Negeri Sukajadi 9 Bandung", Jurnal Teknologi dan Informasi UNIKOM (JATI), Vol. 3, No. 1, Hal. 45-59.

Madcoms. 2012. Adobe Dreamweaver CS6 dan PHP-MySQL Untuk Pemula. Penerbit Andi, Yogyakarta.

Membara, Eka Putra, Liza Yulianti, dan Indra Kanedi. 2014. "Sistem Informasi Akademik SMP Negeri 2 Talang Empat Berbasis Web", Jurnal Media Infotama, Vol. 10, No. 1, Hal. 72-80.

Pressman, Roger S. 2010. Rekayasa Perangkat Lunak : Pendekatan Praktisi, Edisi 7, Penerbit Andi, Yogyakarta. 
Qamaruzzaman, M. H., Prasetya, T., Islamova, S, A., 2018. "Sistem Informasi Berbasis Mobile Benda-Benda Tradisional Pada Museum Balanga Palangkaraya”. Jurnal Sains Komputer dan Teknologi Informasi. Vol 1 Issue 1 e-ISSN 2655-7460. https://doi.org/10.33084/jsakti.v1i1.455

Sam'ani. Annisa, S., Heri., 2018. "Rancang Bangun Aplikasi Pengawasan Dan Pengendalian Komputer Laboratorium Multimedia STMIK Palangkaraya”. Jurnal Sains Komputer dan Teknologi Informasi. Vol 1 Issue 1 e-ISSN 2655-7460.

https://doi.org/10.33084/jsakti.v1i1.548

Simarmata, Janer. 2010 Rekayasa Web, Penerbit Andi, Yogyakarta.

Suryandani, Farid., Basori, dan Dwi Maryono. 2017.'Pengembangan Sistem Informasi Akademik Berbasis Web Sebagai Sistem Pengolahan Nilai Siswa di SMK Negeri 1 Kudus", Jurnal JIPTEK, Vol. 10, No. 1, Hal. 71-82.

Susanti, Melan. 2016. "Perancangan Sistem Informasi Akademik Berbasis Web Pada SMK Pasar Minggu Jakarta”, Jurnal Informatika, Vol. 3, No. 1, Hal. 91-99.

Sutarman. 2012. Pengantar Teknologi Informasi, Bumi Aksara, Jakarta. 